\title{
Aldolase DNA polymorphism in subterranean mole-rats: genetic differentiation and environmental correlates
}

\author{
Eviatar Nevo, \\ Keichiro Joh, $\dagger$ \\ Katsuji Hori† and \\ Avigdor Beiles*
}

\author{
* Institute of Evolution, University of Haifa, Mount \\ Carmel, Haifa 31999, Israel. \\ † Department of Biochemistry, Saga Medical School, \\ Saga 840-01, Japan.
}

We analysed the genetic diversity and environmental correlates of the aldolase $A$ and $B$ genes by means of restriction endonucleases (DNA RFLP analysis), in the four chromosomal species $(2 n=52,54,58$ and 60$)$ of the actively speciating subterranean mole-rats of the Spalax ehrenbergi superspecies in Israel. The results indicated that: (i) both aldolase genes are highly polymorphic; (ii) Fragment frequencies and fragment profiles display geographical patterns and significant ecological correlates; (iii) discriminant analysis largely succeeded in separating the four chromosomal species on the basis of variation of aldolase RFLPs.

\section{INTRODUCTION}

The glycolytic enzyme fructose-1, 6-bisphosphate aldolase (aldolase; EC 4.1.2.13) is a tetrameric protein composed of a specific combination of different subunits A (muscle type), B (liver type) and C (brain type) (Penhoet et al., 1967). These isozymes have the same molecular size $\left(M_{\mathrm{r}}=\right.$ 40,000 each), differ in antigenic properties and in net charges, and have been identified and characterized in many mammals (Horecker et al., 1972; Schapira et al., 1975; Lebherz and Rutter, 1969). The genes encoding these subunits appear to be located separately on the chromosomes. Nevertheless, they seem to be closely related structurally: hence they are thought to have originated by gene duplication during evolution (Penhoet et al., 1967; Benfield et al., 1979, Lai, 1975).

The structure, genomic organization, and expression of the rat aldolase isozyme genes have been the subject of intensive studies in tissue specific expression, regulation, and evolution (reviewed in Hori et al., 1987; see also Joh et al., 1985, 1986; Sakakibara et al., 1985a,b; Mukai et al., 1984, 1986; Tsutsumi et al., 1983, 1984, 1985 and gene mapping in humans in Kukita et al., 1987). However, genetic differentiation and environmental correlates of aldolases in natural populations are largely unknown. Our objective in this research was to study geographic variation of aldolase in the four chromosomal species of molerats of the Spalax ehrenbergi complex across a transect of aridity stress in Israel.

Subterranean mole-rats of the Spalax ehrenbergi superspecies in Israel represent a case of active speciation and adaptive radiation suitable for investigating aldolase polymorphisms. Several reviews highlighting different perspectives describe the multidisciplinary studies on the $S$. ehrenbergi complex both in terms of adaptation and speciation (Nevo 1979, 1982, 1985a, b, 1986a, b, 1988a, $1989,1990)$. The complex comprises four chromosomal species $(2 n=52,54,58,60)$ displaying progressive final stages of chromosomal speciation. Hybrid zones, progressively becoming narrower northward, separate the chromosomal species (Nevo and Bar-El 1976), and along with differential interspecific assortative mating, this provides a measure of the stage of speciation of each species (Nevo 1985a).

The adaptive radiation of the $S$. ehrenbergi superspecies in Israel, from the early Pleistocene to recent times, is closely associated with fossoriality, increasing aridity, progressive deforestation and savannization. It is associated with distinct climatic diversity in both the Mediterranean and steppic climatic regimes: $2 n=52$ in the cool-humid north; $2 n=54$ in the cool-dry north- 


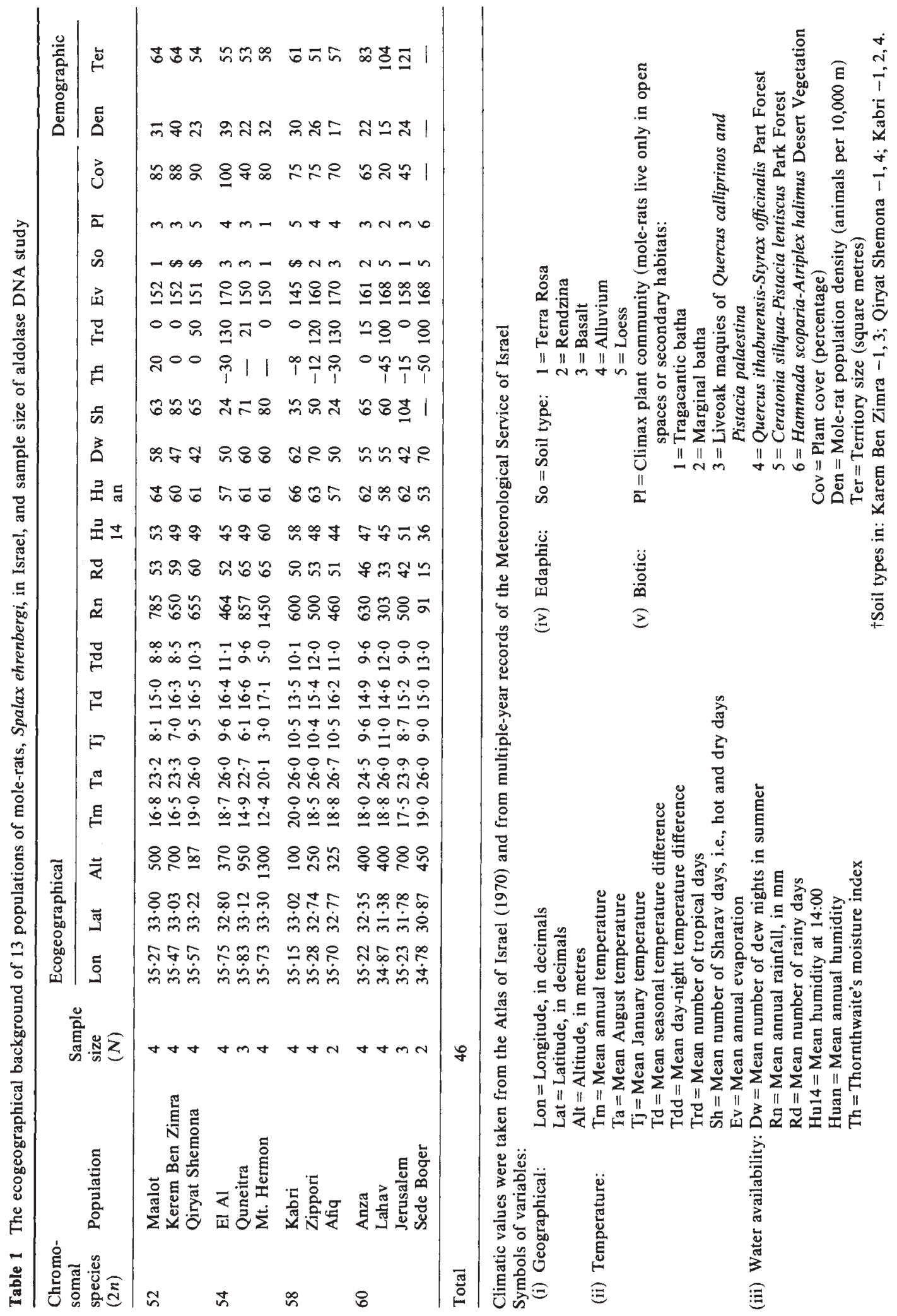


east; $2 n=58$ in the warm-humid centre; finally, $2 n=60$ in the warm-dry south. Noteworthy, aridity increases primarily southward $(2 n=52 \rightarrow 58 \rightarrow 60)$, but also, though less so, eastward $(2 n=52 \rightarrow 54)$. The biology of mole rats is correlated at all levels of organization with the climatic trends of aridity stress.

Allozymic variation has been studied in this superspecies at 30 gene loci (Nevo and Shaw, 1972; Nevo and Cleve, 1978; Nevo, Filippucci and Holmes, in preparation). These studies revealed low levels of allozyme polymorphism and heterozygosity.

Interestingly, all three aldolase isozymes tested electrophoretically, at the protein level proved monomorphic throughout Israel. Here we present evidence indicating that at the DNA level two of the aldolase genes, A (muscle type) and B (liver type) appear very polymorphic. Furthermore, these aldolase DNA polymorphisms appear to be correlated with, and predictable by, the environment, especially aridity stress.

\section{MATERIAL AND METHODS}

\section{Sampling}

We tested aldolase DNA polymorphisms in 46 mole-rats comprising 13 populations and four chromosomal species of the Spalax ehrenbergi superspecies in Israel. A list of these and their ecogeographical background appears in table 1, and distribution in fig. 1. Sede Boqer is a desert isolate involving only about 100 individuals ( Nevo, 1989), hence we analysed only two individuals. The analysis of two DNAs out of the four Afiq animals failed, hence the remaining $N=2$. Live animals were brought from their natural populations and dissected in the laboratory. The tissues were immediately frozen in liquid nitrogen and then stored at $-80^{\circ} \mathrm{C}$.

\section{Southern Blot Analysis}

Chromosomal DNA was isolated from kidney tissue of the different species, using standard methods (Holland, 1983). Each of the DNAs $(10 \mu \mathrm{g})$ was digested separately with two restriction enzymes, EcoRI and HindIII, electrophoresed on a 1 per cent agarose gel, and blotted onto GeneScreen membrane (NEN) according to the protocol of the supplier. Prehybridization and hybridization were performed in a solution containing $4 \times \operatorname{SET}(0.6 \mathrm{M} \mathrm{NaCl}, 4 \mathrm{mM}$ EDTA, $80 \mathrm{mM}$ Tris- $\mathrm{HCl}, p \mathrm{H} \mathrm{7.8)}, 1 \times$ Denhardt's solution $(0.02$

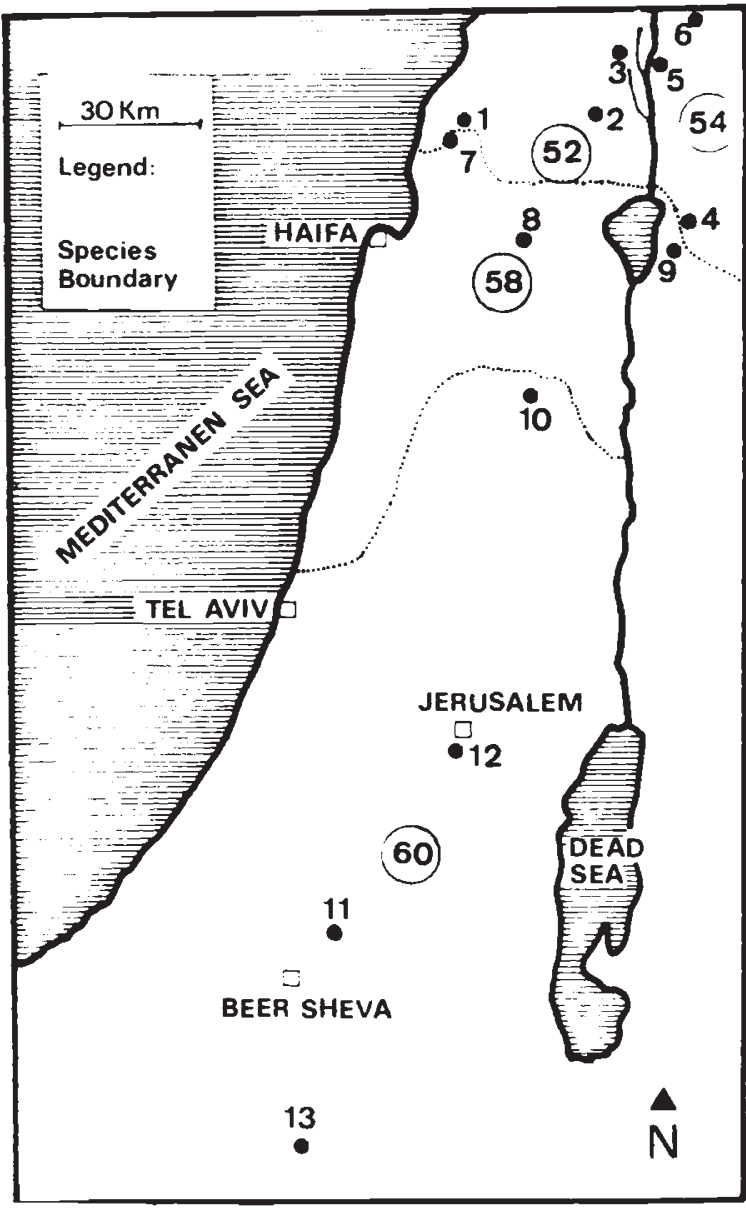

Figure 1 Geographic distribution of the chromosome species and the tested populations of the Spalax ehrenbergi superspecies in Israel. $2 n=52$; (1) Maalot, (2) Kerem Ben Zimra, (3) Qiryat Shemona; $2 n=54$ : (4) El-Al; (5) Quneitra, (6) Hermon; $2 n=58$ : (7) Kabri, (8) Zippori, (9) Afiq; $2 n=60$ : (10) Anza, (11) Lahav, (12) Jerusalem, (13) Sede Boqer (a very small desert isolate in the northern Negev desert).

per cent BSA, 0.02 per cent polyvinylpyrrolidone, 0.02 per cent Ficol), 1 per cent SDS, $200 \mu \mathrm{g} / \mathrm{ml}$ denatured salmon sperm DNA at $62^{\circ} \mathrm{C}$ for 12 to $16 \mathrm{~h}$ and for $48 \mathrm{~h}$, respectively. Two kinds of aldolase cDNA were used as probes: a mixture of pRAAM83 and pRAAM103, cDNA clones of rat aldolase A mRNA (Joh et al. 1985), and pRAB1710, a cDNA of rat aldolase B mRNA (Tsutsumi et al., 1984). They were labelled to $1 \times$ $10^{9} \mathrm{cpm} / \mu \mathrm{g}$ by the procedure of Feinberg and Vogelstein (1983), heat-denatured, and used at a concentration of $10^{6} \mathrm{cpm} / \mathrm{ml}$. After hybridization, filters were rinsed four times with $2 \times$ SET containing 1 per cent SDS at room temperature for $5 \mathrm{~min}$, 


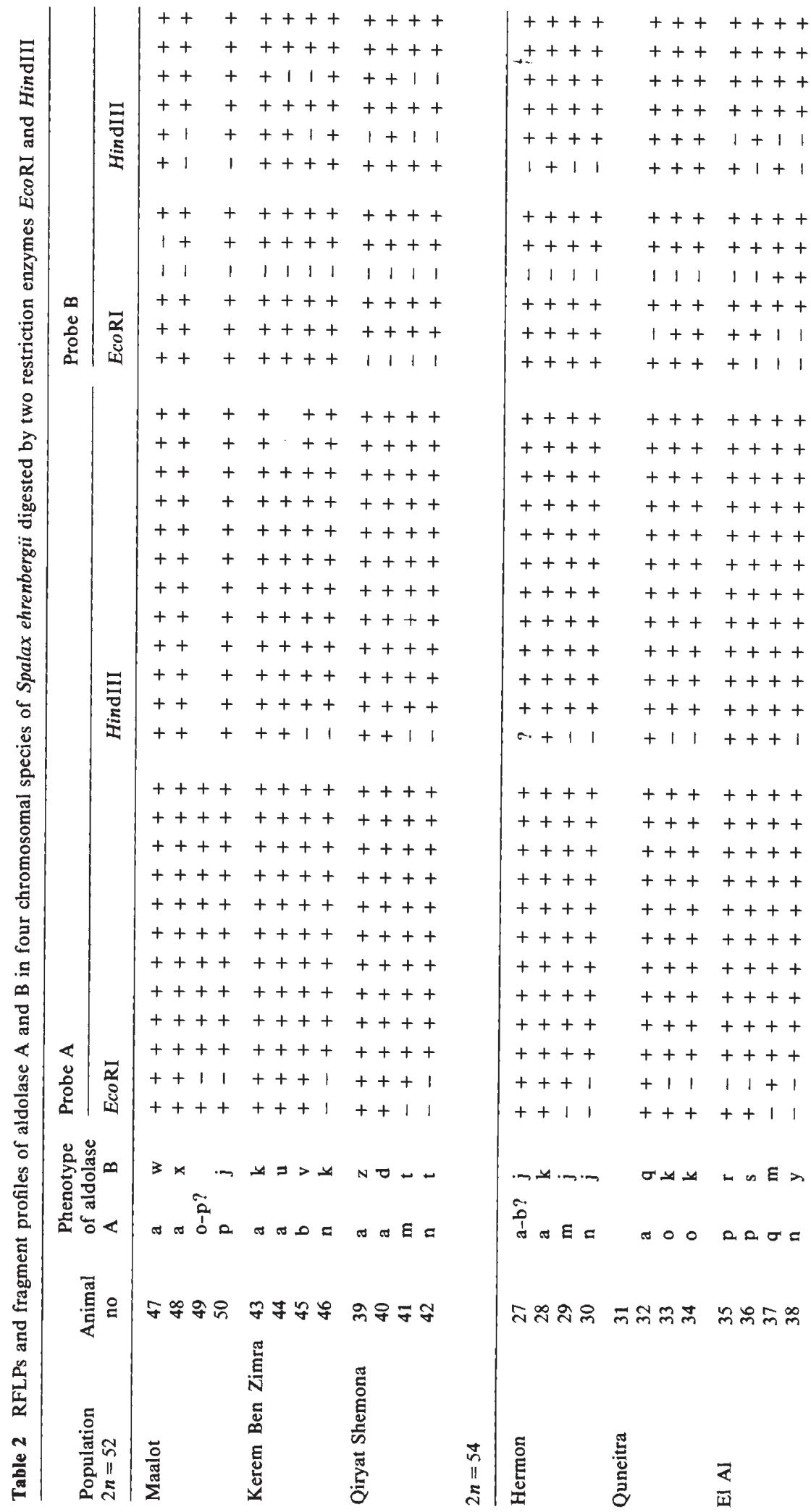




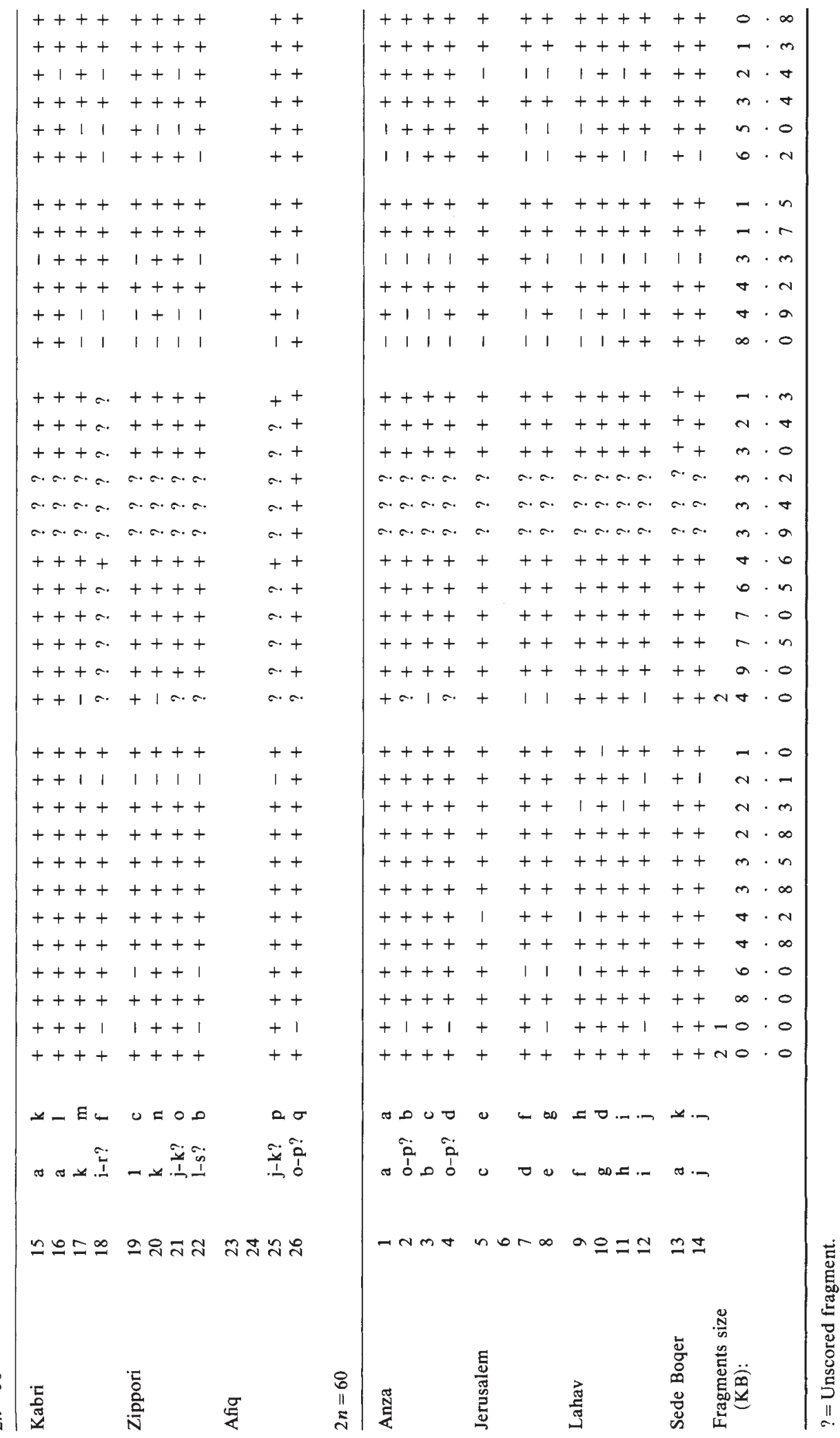


washed twice with the same solution at $56^{\circ} \mathrm{C}$ for $1 \mathrm{~h}$, and autoradiographed at $-70^{\circ} \mathrm{C}$.

\section{Statistical analysis}

We used SPSS-x (1986) statistical programs for uni- and multivariate analyses. We designted fragments by referring first to the gene probe (A or B), then to the restriction enzyme ( $\mathrm{E}$ for Eco RI and $\mathrm{H}$ for HindIII) followed by the kilobase of the fragment; for example AE $2 \cdot 1=$ Probe A, digested by EcoRI and $2 \cdot 1$ kilobase in size.

\section{RESULTS}

\section{Patterns of variation}

The results appear in tables 2-6 and in fig. 2. We have found scorable polymorphisms with both probes (Ald-A and B). For Ald-A we found 12 fragments with both EcoRI and HindIII. For AldB we found six and seven fragments with EcoRI and HindIII, respectively. The fragment distribution appears in table 2. Several patterns are indicated, for each probe and for each restriction enzyme. For probe A, digested with EcoRI, seven of 12 fragments were polymorphic, producing 13 different"fragment profiles" (which are essentially different phenotypes of the aldolase A genotypes). In probe A, digested with HindIII, only one of 12 fragments was polymorphic, producing two different fragment profiles. For probe B, digested by EcoRI, four of six fragments were polymorphic, producing eight different fragment profiles; and with HindIII three of seven fragments were polymorphic, producing eight different fragment profiles.

Fragment frequencies of the 15 polymorphic fragments across the four chromosomal species appear in table 3. Several geographic patterns are apparent. The first pattern displayed high frequency or fixation in the two northern species $(2 n=52,54)$ (e.g., Probe-A, Eco RI, $2 \cdot 1 \mathrm{~kb}$; Probe B, Eco RI, $4.9 \mathrm{~kb}$ ). The second pattern displayed high frequency or fixation in the southern species $(2 n=58,60)$ (e.g., Probe-A Eco RI, $20 \mathrm{~kb})$. The third pattern displayed highest frequency in $2 n=$ 58 , decreasing both southward and northward (e.g., Probe B, EcoRI, $3 \cdot 3 \mathrm{~kb}$ ). The fourth pattern displayed highest frequency in the two mesic species $(2 n=52,58)$ and the lowest frequency in the two xeric species $(2 n=54,60)$ (e.g., Probe B, HindIII, $6.2 \mathrm{~kb}$; an opposite trend is displayed by the $5.0 \mathrm{~kb}$ fragment). The fifth pattern displayed a decrease in frequency in the southern species, $2 n=$
60 (e.g., Probe A, EcoRI, 4.2, 2.3, 1.0 kb). The sixth pattern was opposed to the fifth pattern and displayed decrease in frequency in $2 n=52$ (e.g., Probe B, Eco RI, 1.7 kb). Patterns 4-6 are not significant, but similar patterns in other molecular systems were significant (Nevo, 1990), hence we suspect that they may display biological reality. However, their confirmation clearly needs additional testing.

\section{Geographical trends of phenotypic fragment profile diversity}

The profiles generated for each of the aldolase probes by the two restriction enzymes have been designated alphabetically from profile $A$ to $S$ in aldolase $\mathrm{A}$, and $\mathrm{A}$ to $\mathrm{Z}$ in aldolase $\mathrm{B}$ (see alphabetical designations in table 2). Overall, we defined 17-19 phenotypic profiles in aldolase $A$, and 26 in aldolase B. We calculated for each probe in each of the four chromosomal species, the average number of animals for each of the profiles in table 2 . Consequently, we obtained a profile diversity measure for each species, representing the average number of profiles per ten animals. The profile diversities for each of the four chromosomal species were $6 \cdot 2,6 \cdot 0,7 \cdot 5$ and $8 \cdot 5$ for $2 n=52,54,58$ and 60 respectively. The two southern species $(2 n=58,60)$ displayed higher aldolase DNA diversities than the two northern ones $(2 n=$ $52,54)$.

\section{Discriminant analysis}

We conducted stepwise discriminant analysis (SPSS-x, 1986) based on individual variation across all fragments, and the results are given in table 4 and fig. 3. The program succeeded in separating the four chromosomal species, based on nine chosen fragments (table 4(a)) by two significant discriminant functions (table 4(b)). Pairwise comparison indicates significant differences between the four species (table 4(c)), except between $2 n=52$ and $2 n=54$. Thirty-two of the 43 individuals (excluding the Sede Boqer isolate) analysed $(74.4$ per cent) were correctly classified in their respective species (table $4(d)$ ).

\section{Spearman correlations with environment}

Spearman rank correlations were conducted among the frequency of the DNA fragments, and between the polymorphic fragments and environment (table 5). First, Spearman intercorrelations between fragments are relatively low, mostly non- 


$\begin{array}{llllllllllllllllllllllllll}1 & 2 & 3 & 4 & 5 & 7 & 8 & 9 & 10 & 11 & 12 & 13 & 14 & 15 & 16 & 17 & 18 & 19 & 20 & 21 & 22 & 25 & 26 & 27\end{array}$
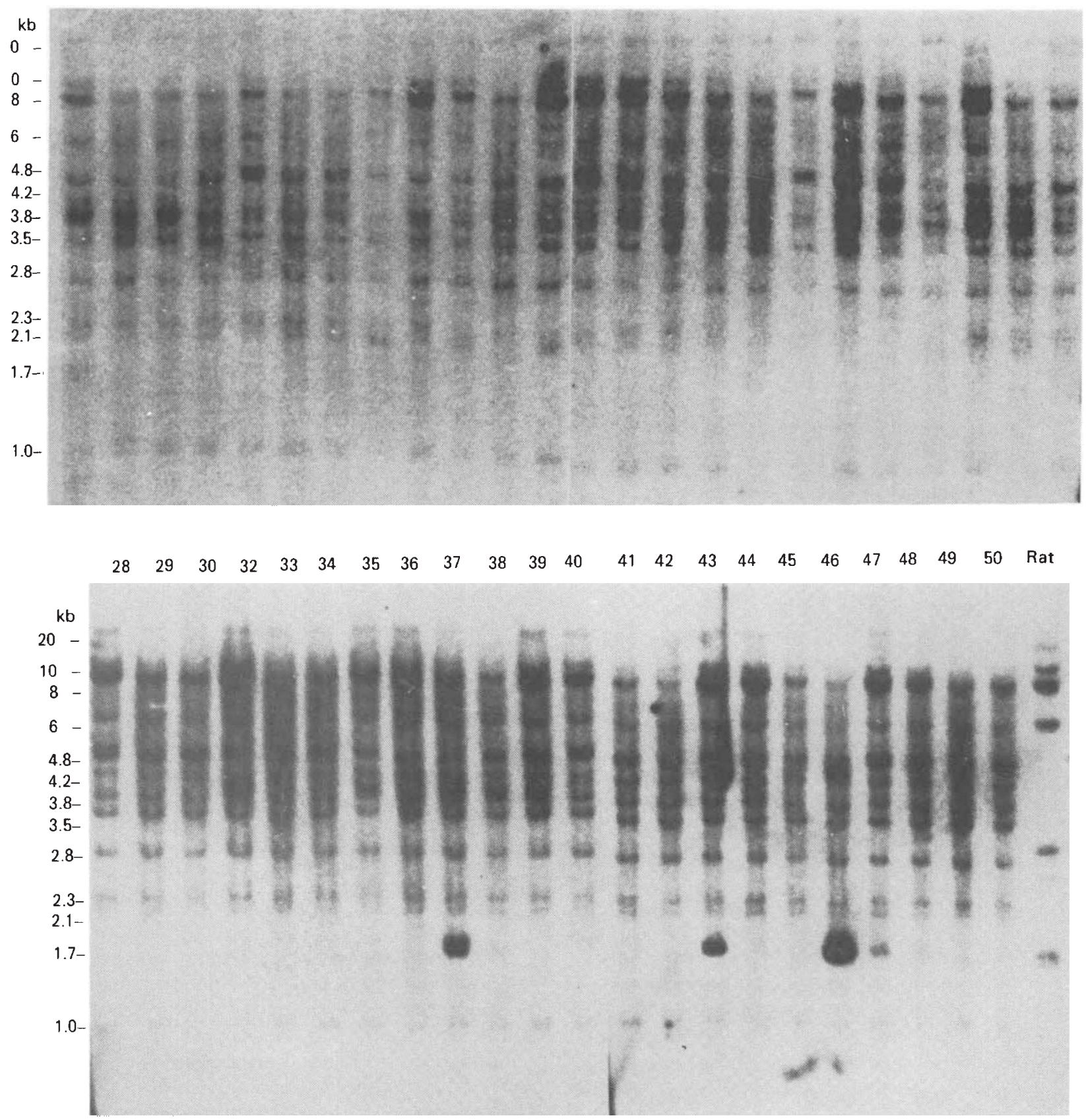

Figure 2 Allelic fragments of aldolase A and B genes resulting from digestion with EcoRI.

significant, and ranging between 0.01 to 0.48 . Second, Spearman rank correlations were calculated between the population means of fragment profile frequencies defined as phenotypes in table 2 with representative ecogeographical variables that appear in table 1. Six fragment profiles out of the 15 analysed showed no correlation at all with any of the environmental variables. Six fragments (AE 2.3, AE 2.1, AE 20.0, BE 8.0, BE 4.9 and $\mathrm{BE}$ $3 \cdot 3)$ displayed many correlations with temperature 


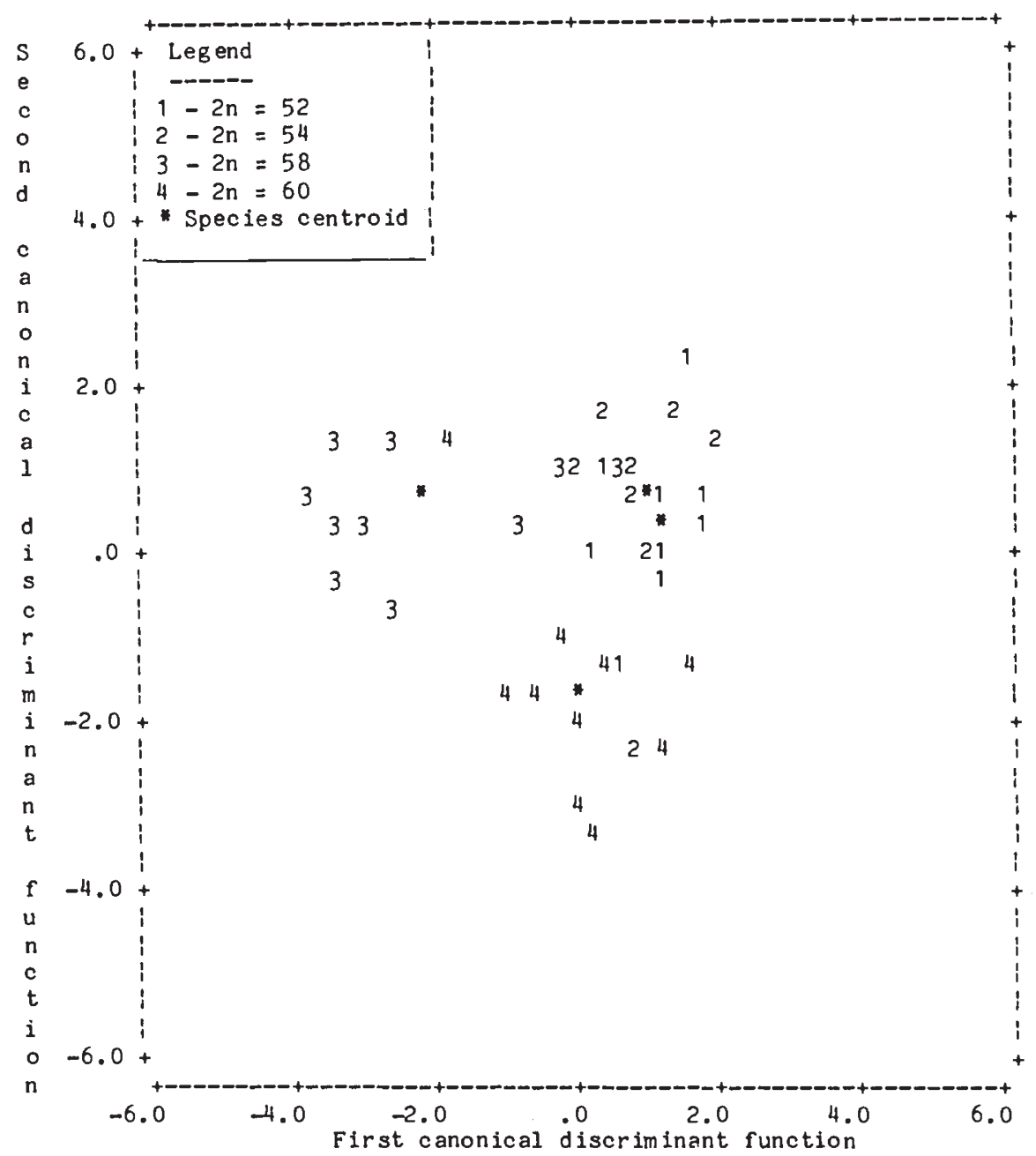

Figure 3 Discriminant analysis of the four chromosomal species of $S$. ehrenbergi based on nine fragments of aldolase A and B.

and rainfall variables (see table 5 for details). These significant correlations, with a high proportion of the climatic variables comprising 40 per cent of the aldolase polymorphisms, are above those expected by chance.

\section{Multiple regression analysis}

In order to explain the geographical patterning of the aldolase polymorphisms we used 12 population means of the fragment profile frequencies or phenotypes (see table 2) as dependent variables, and ecogeographical variables as independent ones, in a stepwise multiple regression analysis (MR). Two or three primarily climatic combina- tions plus plant coverage, explain a substantial amount of the aldolase RFLPs, in both genes (table $6)$. For example, 79 per cent of the variance of $\mathrm{AE}$ $4 \cdot 2$ is significantly explained by a three-variable combination involving number of rainy days, altitude and mean annual temperature; 74 per cent of the variance of $\mathrm{BE} 4 \cdot 9$, is significantly explained by daily temperature difference (Tdd), number of dew nights in summer (Dw) and evaporation (Ev). Likewise, 62 per cent of the variance of $\operatorname{AE~} 20 \cdot 0$, is significantly explained by a two-variable combination of seasonal temperature difference (Td) and plant cover (Cov). In general, temperature and water availability variables played a major role in explaining (directly or indirectly) the variance in fragment frequencies of both aldolase loci A and B. 
Table 3 Frequencies of aldolase RFLPs of four chromosomal species of Spalax ehrenbergi digested by two restriction enzymes EcoRI and HindIII

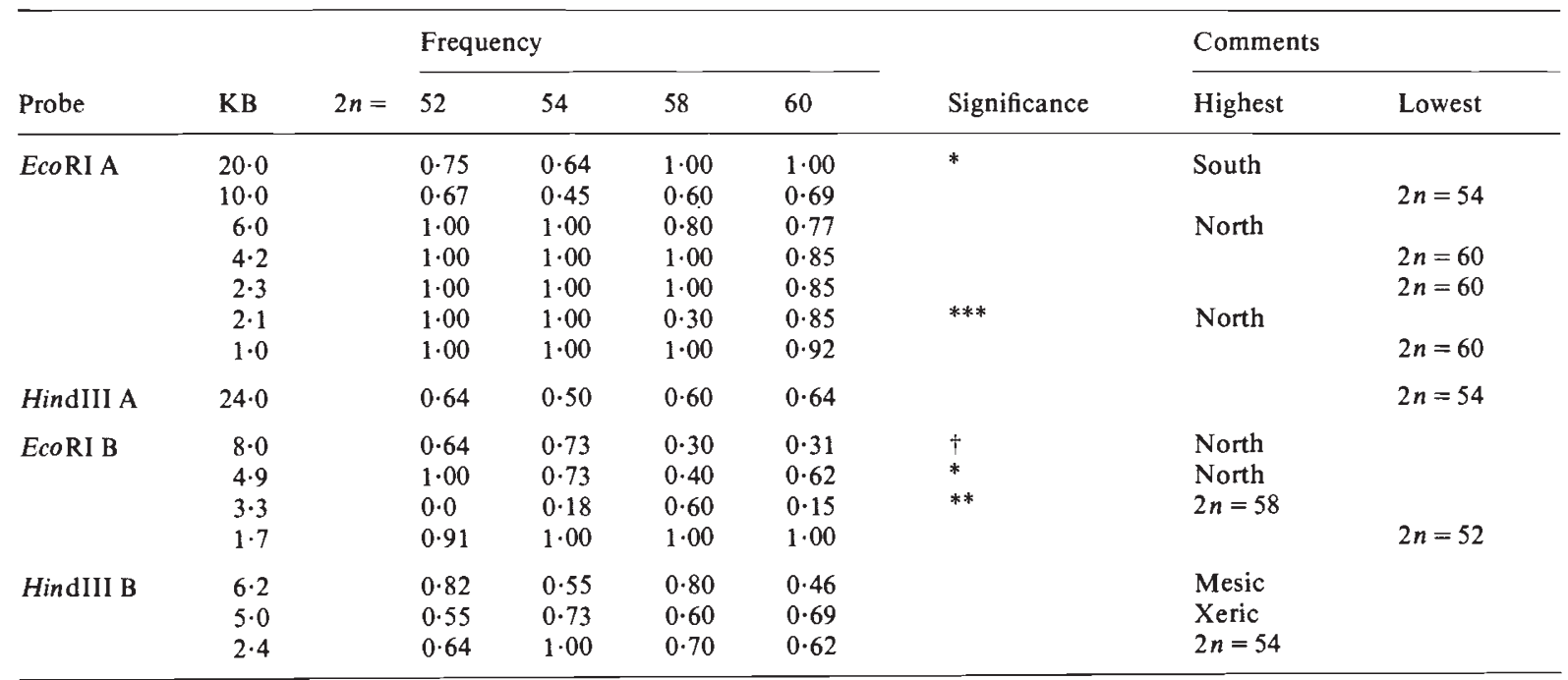

Significance by Kruskal-Wallis one-way ANOVA.

${ }^{*} P<0.05$.

** $P<0.01$.

*** $P<0.001$.

$+P<0 \cdot 10$.

\section{DISCUSSION}

The glycolytic enzyme fructose-1,6-bisphosphate aldolase, widely distributed in almost all organisms, catalyzes the following reversible reaction, yielding two different triose phosphates: fructose1,6-bisphosphate = dihydroxyacetone phosphate + D-glyceraldehyde-3-phosphate. Variation in aldolase activity is achieved by various mechanisms. First, there are three isozymic forms, aldolase A (muscle type), B (liver type) and C (brain type), that evolved through gene duplication (Scandalios, 1983), displaying tissue and developmental stage specificities (Lebherz and Rutter, 1969; Horecker et al., 1972). Dramatic changes in the expression of aldolase A occur during ontogenesis and carcinogenesis of rat liver (Gracy et al., 1970; Horecker et al., 1972). Second, it has been found recently that three aldolase A mRNA species with different molecular sizes expressed tissuespecifically in rat (Joh et al., 1985; Mukai et al., 1986). Furthermore, additional study of aldolase $\mathrm{A}$ indicated that a single gene of rat aldolase $\mathrm{A}$ has multiple promoters allowing the tissue-specific generation of three species of mRNA by alternative usage of two exons encoding the $5^{\prime}$ noncoding regions of the mRNAs (Joh et al., 1986). This is in contrast to the pattern of rat and chicken
mRNA is transcribed (Tsutsumi et al., 1985; Burgess and Penhoet, 1985). This distinction between aldolase A multiple promoters generating three mRNA forms notwithstanding, many features, especially the exon-intron structure of rat aldolase $A$ and $B$ gene, are essentially similar. This indicates that both genes have evolved from a common ancestral gene.

To the variation found hitherto in aldolases based on gene duplications, tissue and ontogenetic specificities, and the multiple promoters to the same gene producing multiple mRNA forms, we now add aldolase polymorphisms (RFLPs) in both aldolase A and B of the mole-rat, Spalax ehrenbergi. This discovery is particularly interesting in view of (i) the monomorphism reported earlier for the three isozymes (aldolase A, B, C) in mole rats of the Spalax ehrenbergi superspecies (Nevo and Shaw, 1972), (ii) the environmental correlates of the RFLPs, and (iii) polymorphism in the Sede Boqer desert isolate. We will now discuss these three aspects in turn.

\section{Monomorphism of isozyme proteins and polymorphism of DNA}

Out of 30 isozymic genes analysed in the $S$. ehrenbergi superspecies, 14 gene loci proved polymor- 
Table 4 Discriminant analysis of aldolase RFLPs of four chromosomal species of Spalax ehrenbergi in Israel

A. Variables chosen:

\begin{tabular}{|c|c|c|c|c|}
\hline Step & Entered/removed & \multicolumn{3}{|c|}{ Summary table } \\
\hline 1 & $\mathrm{AE} 2 \cdot 1$ & 1 & 0.46211 & 0.0001 \\
\hline 2 & $\mathrm{BE} 8 \cdot 0$ & 2 & 0.38269 & 0.0001 \\
\hline 3 & AE 20.0 & 3 & $0 \cdot 29808$ & 0.0001 \\
\hline 6 & $\mathrm{BE} 3 \cdot 3$ & 6 & $0 \cdot 17287$ & 0.0001 \\
\hline 7 & $\mathrm{AE} 2 \cdot 3$ & 7 & $0 \cdot 15169$ & 0.0001 \\
\hline 8 & $\mathrm{BH} 5 \cdot 0$ & 8 & $0 \cdot 13549$ & 0.0001 \\
\hline 9 & BE4.9 & 9 & $0 \cdot 12336$ & 0.0001 \\
\hline
\end{tabular}

B. Significance of discriminant functions

\begin{tabular}{lllllllr}
$\begin{array}{l}\text { Canonical } \\
\text { discriminant } \\
\text { function }\end{array}$ & Eigenvalue & $\begin{array}{l}\text { Canonical } \\
\text { correlation }\end{array}$ & $\begin{array}{l}\text { After } \\
\text { function }\end{array}$ & $\begin{array}{l}\text { Wilks' } \\
\text { lambda }\end{array}$ & $\begin{array}{l}\text { Chi- } \\
\text { squared }\end{array}$ & df & Significance \\
\hline 1 & 1.9212 & $0 \cdot 811$ & 0 & $0 \cdot 1234$ & $74 \cdot 290$ & 27 & $0 \cdot 0001$ \\
2 & 1.0062 & 0.708 & 1 & 0.3604 & $36 \cdot 234$ & 16 & $0 \cdot 0027$ \\
3 & 0.3832 & 0.526 & 2 & 0.7229 & 11.517 & 7 & $0 \cdot 1176$
\end{tabular}

C. Pairwise comparison
Species:
1. $2 n=52$
2. $2 n=54$
3. $2 n=58$

\begin{tabular}{|c|c|c|c|c|}
\hline 2. $2 n=54$ & $\begin{array}{l}F= \\
P=\end{array}$ & $\begin{array}{l}1 \cdot 3696 \\
0 \cdot 2439\end{array}$ & & \\
\hline 3. $2 n=58$ & $\begin{array}{l}F= \\
P=\end{array}$ & $\begin{array}{l}5 \cdot 5785 \\
0 \cdot 0001\end{array}$ & $\begin{array}{l}5 \cdot 1379 \\
0 \cdot 0003\end{array}$ & \\
\hline 4. $2 n=60$ & $\begin{array}{l}F= \\
P=\end{array}$ & $\begin{array}{l}3 \cdot 0010 \\
0 \cdot 0108\end{array}$ & $\begin{array}{l}3 \cdot 3148 \\
0.0061\end{array}$ & $\begin{array}{l}4.5821 \\
0.0007\end{array}$ \\
\hline
\end{tabular}

Each $F$ statistic has 10 and 30 degrees of freedom.

D. Classification results

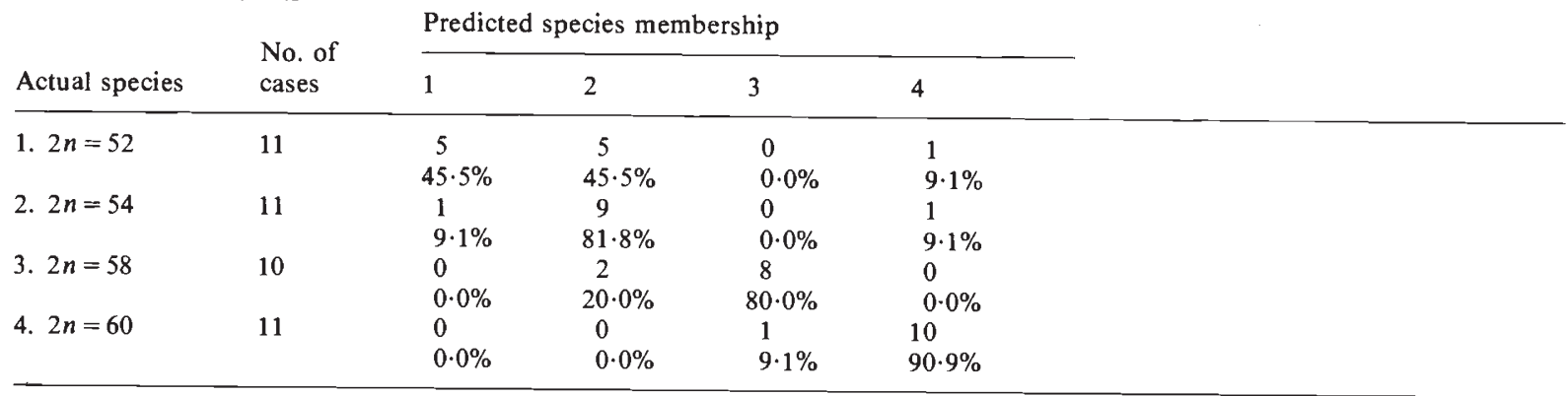

74.4 per cent of the cases were correctly classified.

phic (with low level of polymorphism), whereas 16 , including the three aldolase genes, proved monomorphic. The discrepancy between the isozyme monomorphism and extensive DNA polymorphism of aldolase A and B reported here is explicable on several grounds. First, routine gel electrophoresis reveals only some, not all, of the variation involved. Second, the redundancy of the code permits changes in codons without a change in amino acid sequence. Third, mutations in introns are not expressed in the translated message. Fourth, mutations at the flanking regions of the gene are not expressed in gene product, but they may affect regulation. 


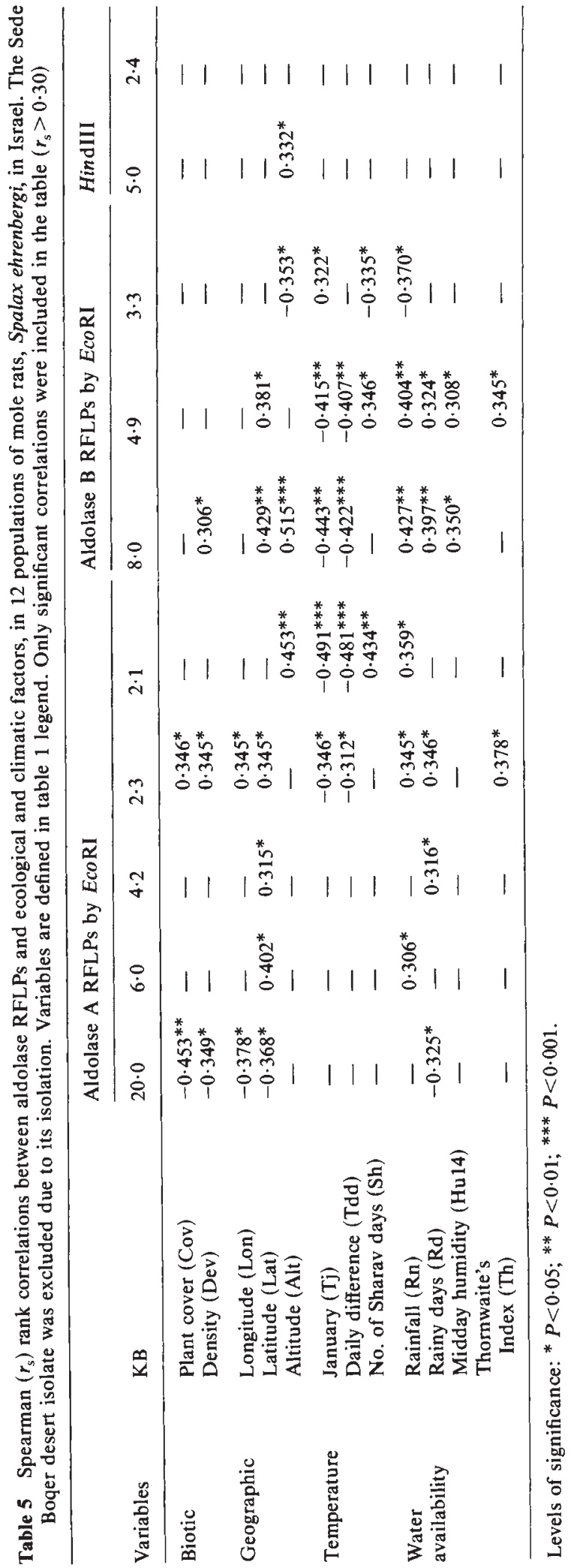


Table 6 Coefficients of multiple regressions $\left(R^{2}\right)$ of aldolase DNA fragments frequencies (as the dependent variables) and climatic and ecological variables (as independent variables) in 12 populations of Spalax ehrenbergi, (for abbreviations see table 1)

\begin{tabular}{|c|c|c|c|}
\hline \multirow{2}{*}{$\frac{\text { Fragment }}{\text { AE } 20 \cdot 0}$} & \multicolumn{3}{|c|}{ Stepwise model } \\
\hline & $\begin{array}{l}\text { Td } \\
0.434^{*}\end{array}$ & $\begin{array}{l}\text { Td Cov } \\
0.619^{*}\end{array}$ & \\
\hline $\mathrm{AE} 10 \cdot 0$ & $\begin{array}{l}\mathrm{Hu} 14 \\
0 \cdot 212\end{array}$ & $\begin{array}{l}\text { Hu14 Dw } \\
0.338\end{array}$ & $\begin{array}{l}\text { Hu14 Dw Rd } \\
0.450\end{array}$ \\
\hline AE 6.0 & $\begin{array}{l}\text { Rd } \\
0 \cdot 236\end{array}$ & & \\
\hline $\mathrm{AE} 4 \cdot 2$ & $\begin{array}{l}\text { Rd } \\
0.501 * *\end{array}$ & $\begin{array}{l}\text { Rd Alt } \\
0 \cdot 706^{* *}\end{array}$ & $\begin{array}{l}\text { Rd Alt Tm } \\
0.792^{* *}\end{array}$ \\
\hline $\operatorname{AE} 2 \cdot 3$ & $\begin{array}{l}\text { Cov } \\
0.441^{*}\end{array}$ & $\begin{array}{l}\text { Cov Rd } \\
0.571^{*}\end{array}$ & \\
\hline $\mathrm{AE} 2 \cdot 1$ & $\begin{array}{l}\text { Dw } \\
0.352^{*}\end{array}$ & $\begin{array}{l}\text { Dw Ta } \\
0.717^{* *}\end{array}$ & \\
\hline AE 1.0 & $\begin{array}{l}\text { Cov } \\
0 \cdot 441^{*}\end{array}$ & $\begin{array}{l}\text { Cov Rd } \\
0.571^{*}\end{array}$ & \\
\hline BE $8 \cdot 0$ & $\begin{array}{l}\mathrm{Tj} \\
0 \cdot 428^{*}\end{array}$ & & \\
\hline BE 4.9 & $\begin{array}{l}\text { Tdd } \\
0 \cdot 512^{* *}\end{array}$ & $\begin{array}{l}\text { Tdd Dw } \\
0.655^{* *}\end{array}$ & $\begin{array}{l}\text { Tdd Dw Ev } \\
0.739^{* *}\end{array}$ \\
\hline BE $3 \cdot 3$ & $\begin{array}{l}\operatorname{Tm} \\
0 \cdot 206 \dagger\end{array}$ & & \\
\hline BH 6.2 & $\begin{array}{l}\mathrm{Ta} \\
0 \cdot 152\end{array}$ & $\begin{array}{l}\text { Ta Rd } \\
0.586^{*}\end{array}$ & $\begin{array}{l}\text { Ta Rd Cov } \\
0.749^{* *}\end{array}$ \\
\hline BH 5.0 & $\begin{array}{l}\text { Tm } \\
0 \cdot 339^{*}\end{array}$ & $\begin{array}{l}\text { Tm Dw } \\
0 \cdot 514^{*}\end{array}$ & \\
\hline BH $2 \cdot 4$ & $\begin{array}{l}\text { Dw } \\
0.207\end{array}$ & $\begin{array}{l}\text { Dw Td } \\
0.451 \dagger\end{array}$ & \\
\hline
\end{tabular}

Level of significance: ${ }^{* * *} P<0.001 ;{ }^{* *} P<0.01$; $^{*} P<0.05$; $\dagger P<0 \cdot 10$.

\section{Environmental correlates of aldolase RFLPS}

We hypothesize that the RFLPs found in aldolase $A$ and $B$, may, at least partly, function in regulation and gene expression. The evidence supporting this hypothesis comes primarily from the environmental correlates (tables 5 and 6), and from the fragment profile diversities (table 2 ). The climatic correlates of six fragments, primarily with temperature and rainfall variation, and their high level and significant explanation in the multiple regression analysis, are impressive. In particular, it appears that while nine fragments show no, or few significant environmental correlates, hence might be the result of chance alone, the six fragments significantly correlated with climate may suggest deterministic climatic selection on these variants, either directly or indirectly.
The substantial importance of climatic selection, particularly by aridity stress on allozymic variation, has been demonstrated in 38 species of plants, invertebrates and vertebrates across Israel (Nevo, 1983, 1990). In particular 21 of the 38 species which were sampled across the entire mesic-xeric gradient, displayed positive correlation between heterozygosity of individual loci, as well as overall heterozygosity, with climatic heterogeneity and unpredictability (Nevo and Beiles, 1988a). Recently, we have also demonstrated climatic selection between ribosomal DNA nontranscribed spacer polymorphism in $S$. ehrenbergi across the same transect of increasing aridity stress analyzed here for aldolase A and B (Nevo and Beiles, 1988b).

Remarkably, aldolase fragment profile diversity increases from the northern $(2 n=52,54)$ to southern $(2 n=58,60)$ species. This pattern parallels that of allozymic heterozygosity discussed above. Aldolase DNA diversity, as well as allozymic heterozygosity are positively correlated with rainfall variation and unpredictability; both increase southward from the Mediterranean to the steppic and desert regions. This positive correlation between genetic and environmental variation, i.e., the niche width variation hypothesis (Van Valen, 1965), substantiates the importance of ecological heterogeneity in population genetic differentiation of aldolases.

It is plausible to hypothesize that the level of genetic diversity may primarily relate to the buffering and homeostatic effect of heterozygosity of metabolically vital enzymes related to the energetic balance (Koehn, 1990). Protein heterozygosity is apparently associated with developmental homeostasis and physiological function. The fitness of individuals in ecologically uncertain environments appears at least partially related to the level of heterozygosity. This pattern which corroborates theoretical predictions (Turelli and Ginzburg, 1983) may also be true for DNA polymorphism as demonstrated here for aldolase DNA diversity. Testing of additional DNA polymorphisms is needed before any generality may be drawn.

\section{Polymorphism in the small desert Sede Boqer isolate}

The Sede Boqer desert isolate in the Northern Negev may have been disjuncted more than 10,000 years ago from the main range of $2 n=60$, and its current population size is very small, in the order of 100 individuals (Nevo, 1989). Theoretically, this population which underwent a distinct bottleneck- 
ing during the late Pleistocene and Holocene times, and is therefore expected to be highly inbred, should have been highly homozygous for most genotypic and phenotypic systems (Nei et al., 1975). By contrast, the results obtained here for aldolases, indicate polymorphism in aldolases with a sample of two individuals only! Additional genetic polymorphisms were found in the Sede Boqer isolate for other allozymes (esterases), mtDNA, and myosin heavy chain, Per-homologous sequence and chromosomal polymorphisms (reviewed in Nevo 1989 and 1990). Recently, we have also found polymorphism in the Sede Boqer isolate in the major histocompatibility complex (MHC) (Ben Shlomo et al., 1988). In addition phenotypic variances have been also found in the Sede Boqer isolate in morphological, physiological and behavioural parameters. These genotypic polymorphisms and phenotypic diversities are probably the result of climatic balancing selection (Nevo, 1988b, 1989). We suggest that direct climatic selection also affects the evolution of aldolase polymorphisms at the DNA level. This hypothesis is testable indirectly by the correlative methodology and directly by biochemical and physiological analyses.

Acknowledgements We thank the Israeli Discount Bank Chair of Evolutionary Biology, and the Ancell-Teicher Research Foundation for Genetics and Molecular Evolution established by Florence and Theodore Baumritter of New York, for financial support of this research.

\section{REFERENCES}

ATLAS OF ISRAEL. 1970. Ministry of Labour, Jerusalem and Elsevier Publ. Co. Amsterdam.

BEN-SHLOMO, R., FIGUEROA, F., KLEIN, J. AND NEVO, E. 1988. Mhc class II polymorphisms within and between species of Spalax ehrenbergi in Israel. Genetics, 119, 141-149.

BENFIELD, P. A., FORCINA, B. G., GIBBONS, I. AND PERHAM, B. L. 1979. Extended Amino Acid Sequences around the Active-site Lysine Residue of Class-I Fructose 1,6-Bisphosphate Aldolases from Rabbit Muscle, Sturgeon Muscle, Trout Muscle and Ox Liver. Biochem. J., 183, 429-444.

BURGESS, D. G. AND PENHOET, E. E. 1985. Characterization of the chicken aldolase B gene. J. biol. Chem., 260, 46064614.

FEINBERG, A. P. AND VOGELSTEIN, B. 1983. A technique for radiolabeling DNA restriction endonuclease fragments to high specific activity. Analyt. Biochem., 132, 6-13.

GRACY, R. W., LACKO, A. G., BROX, L. W., ADELMAN, R. C. AND HORECKER, B. L. 1970. Structural relations in aldolases purified from rat liver and muscle and Novikoff heptoma. Arch. Biochem. Biophys., 136, 480-490.
HOlland, I. B. (Course Director). 1983. Basic cloning tech niques: Course manual. University of Leicester, Leicester, United Kingdom.

HORECKER, B. L., TSOLAS, O. AND LAI, C. Y. 1972. Aldolases. In Boyer P. D. (ed.) The Enzymes, vol 7, Academic Press, New York.

HORI, K., MUKAI, T., JOH, K., ARAI, Y., SAKAKIB, M. AND YATSUKI, H. 1987. Structure and expression of human and rat aldolase isozyme genes: multiple mRNA species of aldolase A produced from a single gene isozymes $C$ urr. Top. Biol. Med. Res. molec. cell. Biol. 14, 153-175.

JOH, K., MUKAI, T., YATSUKI, H. AND HORI, K. 1985. Rat aldolase A messenger RNA: The nucleotide sequence and multiple mRNA species with different 5 ' noncoding regions from a single rat aldolase A gene. J. molec. Biol. 190, 401-410.

JOH, K., ARAI, Y., MUKAI, T. AND HORI, K. 1986. Expression of three mRNA species differing in their $5^{\prime}$ noncoding regions from a single rat aldolase A gene. J. molec. Biol., $190,401-410$.

KOEHN, R. K. 1990. Heterozygosity and growth in marine bivalves: comments on the Paper by Zourous, Romero-Dorey and Mallet (1988). Evolution, 44, 213-218.

KUKITA, A., YOSHIDA, M. C., FUKUSHIGE, S., SAKAKIBARA, M., JOH, K. MUKAI, T. AND HORI, K. 1987. Molecular gene mapping of human aldolase $(A L D O A)$ gene to chromosome 16. Hum. Genet., 76, 20-26.

LAI, C. Y. 1975. Studies on the structure of rabbit muscle aldolase determination of the primary structure of the $\mathrm{COOH}$-terminal $\mathrm{BrCN}$ peptide: the complete sequence of the subunit polypeptide chain. Arch. Biochem. Biophys., $166,358-368$.

LEBHERZ, H. G. AND RUTTER, W. J. 1969. Distribution of fructose diphosphate aldolase variants in biological systems. Biochemistry, 8, 109-121.

MUKAI, T., JOH, K., ARAI, Y., YATASUKI, H. AND HORI, K 1986. Tissue-specific expression of rat aldolase A mRNAs. Three molecular species differing only in the $5^{\prime}$ terminal sequences. J. biol. Chem., 261, 3347-3354.

MUKAI, T., JOH, K., MIYAHARA, H., SAKAKIBARA, M., ARAI, Y. AND HORI, K. 1984. Different expression of rat aldolase A mRNA in the skeletal muscle an ascites hepatoma cells. Biochem. Biophys. Res. Commun., 119, 525-581.

NEI, M., MARUYAMA, T. AND CHAKRABORTY, R. 1975. The bottleneck effect and genetic variability in populations. Evolution, 29, 1-10.

NEVO, E. 1979. Adaptive convergence and divergence of subterranean mammals. Ann. Rev. Ecol. Syst., 10, 269-308.

NEVO, E. 1982. Speciation in subterranean mammals. In Barigozzi, C. (ed.) Mechanisms of Speciation. Alan R. Liss, Inc., New York, pp. 191-218.

NEVO, E. 1983. Population genetics and ecology: the interface. In Bendall, D. S. (ed.) Evolution from Molecules to Men, Cambridge University Press, Cambridge, pp. 287-321.

NEVO, E. 1985a. Speciation in action and adaptation in subterranean mole rats: Patterns and theory. Boll. Zool., 52, 65-95.

NEVO, E. 1985b. Ecological and populational correlates of allozyme polymorphisms in mammals. Acta zool. Fenn., $170,25-29$.

NEVO, E. 1986a. Mechanisms of adaptive speciation at the molecular and organismal levels. In Karlin, S. and Nevo, E. (eds) Evolutionary Processes and Theory, Academic Press, New York, pp. 439-474.

NEVO, E. 1986b. Evolutionary behavior genetics in active speciation and adaptation of fossorial mole rats. Accad. Naz. Lincei, 259, 39-109. 
NEVO, E. 1988a. Natural selection in action: The interface of ecology and genetics in adaptation and speciation at the molecular and organismal levels. In Tchernov, E. and Yom-Tov, Y. (eds) Zoogeography of Israel, Dr. Munk Publishing, Holland, pp. 411-438.

NEVO, E. 1988b. Genetic diversity in nature: Patterns and theory. Evol. Biol., 23, 217-247.

NEVO, E. 1989. Modes of speciation: The nature and role of peripheral isolates in the origin of species. In Giddings, L. V., Kaneshiro, K. Y. and Anderson, W. W. (eds) Genetics, Speciation and the Founder Principle, Oxford University Press, Oxford, pp. 205-236.

NEVO, E. 1990. Evolutionary theory and processes of active speciation and adaptive radiation in subterranean mole rats, Spalax ehrenbergi superspecies in Israel. Evol. Biol. (In press).

NEVO, E. AND BAR-EL, H. 1976. Hybridization and speciation in fossorial mole rats. Evolution, 30, 831-840.

NEVO, E. AND BEILES, A. 1988a. Genetic parallelism of protein polymorphism in nature: Ecological test of the neutral theory of molecular evolution. Biol. J. Linn. Soc., 35, 229245.

NEVO, E. AND BEILES, A. 1988b. Ribosomal DNA nontranscribed spacer polymorphism in subterranean mole rats: Genetic differentiation, environmental correlates, and phylogenetic relationships. Evol. Ecol, 2, 139-156.

NEVO, E. AND CLEVE, H. 1978. Genetic differentiation during speciation. Nature, 275, 125-126.

NEVO, E. AND SHAW, C. 1972. Genetic variation in subterranean mammals. Biochem. Genet., 7, 235-241.

PENHOET, E. E., KOCKMAN, M. VALENTINE, R. AND RUTTER, W. J. 1967. The subunit structure of mammalian fructose diphosphate aldolase. Biochemistry, 6, 2940-2949.

SAKAKIBARA, M., MUKAI, T. AND HORI, K. 1985a. Nucleotide sequence of a cDNA for human aldolase A messenger RNA in the liver. Biochem. biophys. Res. Commun., 131, 413-420.
SAKAKIBARA, M., MUKAI, T., YATSUKI, H. AND HORI, K. $1985 \mathrm{~b}$. Human aldolase isozyme gene: The structure of multispecies aldolase B mRNAs. Nucleic Acids Res., 13, 5055-5059.

SCANDALIOS, J. G. 1983. Molecular varieties of isozymes and their role in studies of gene regulation and expression during eukaryotic development. In Rattazzi, M. C., Scandalios, J. G. and Whitt, G. S. (eds) Isozymes: Current Topics in Biological and Medical Research, Alan R. Liss, New York, pp. 1-31.

SCHAPIRA, F., HATZFELD, A. AND WEBER, A. 1975. In Markert, C. L. (ed.) Isozymes Acedemic Press, New York, pp. 9871003.

SPSS-X, 1986. User's Guide, 2nd edn, McGraw Hill, New York.

TSUTSUMI, K., MUKAI, T., HIDAKA, S., MIYAHARA, H. TSUTSUMI, R., TANAKA, T., HORI, K. AND ISHIKAWA, K. 1983. Rat aldolase isozyme gene. Cloning and characterization of cDNA for aldolase B messenger RNA. J. biol. Chem., $258,6537-6542$.

TSUTSUMI, K., MUKAI, T., TSUTSUMI, R., MORI, M., DAIMON, M., TANAKA, T., YATSUKI, H., HORI, K. AND ISHIKAWA, K. 1984. Nucleotide sequence of rat liver aldolase B messenger RNA. J. biol. Chem., 259, 14572-14575.

TSUTSUMI, K., MUKAI, T., TSUTSUMI, R., HIDAKA, S., ARAI, Y., HORI, K. AND ISHIDAWA, K. 1985. Structure and genomic organization of the rat aldolase B gene. J. molec. Biol., 181, 153-160.

TURELLI, M. AND GINZBURG, L. R. 1983. Should individual fitness increase with heterozygosity? Genetics, 104, 191209.

VAN VALEN, L. 1965. Morphological variation and width of ecological niche. Am. Nat., 99, 377-390. 